\title{
The Last Frontier
}





\section{The Last Frontier}

Imagining Other Worlds, from the Copernican Revolution to Modern Science Fiction

\section{KARL S. GUTHKE}

TRANSLATED BY

HELEN ATKINS

\section{Cornell University Press}


Originally published as Der Mythos der Neuzeit (C) A. Francke AG Verlag Bern, 1983.

\section{English translation copyright (C) 1990 by Cornell University}

All rights reserved. Except for brief quotations in a review, this book, or parts thereof, must not be reproduced in any form without permission in writing from the publisher. For information, address Cornell University Press, 124 Roberts Place, Ithaca, New York 14850.

English translation first published 1990 by Cornell University Press.

The publisher gratefully acknowledges the assistance of Inter Nationes in defraying part of the cost of translation.

\section{Library of Congress Cataloging-in-Publication Data}

Guthke, Karl Siegfried, 1933-

[Mythos der Neuzeit. English]

The last frontier : imagining other worlds, from the Copernican revolution to modern science fiction / Karl S. Guthke.

p. $\mathrm{cm}$.

Translation of: Der Mythos der Neuzeit.

ISBN o-8014-1680-9 (alk. paper).-ISBN o-8014-9727-2 (pbk.: alk. paper)

1. Science-History. 2. Science-Philosophy. I. Title.

Q125.G96513 1990

$509-$ dc20

(2) The paper used in this publication meets the minimum requirements of the American National Standard for Permanence of Paper for Printed Library Materials Z39.48-1984. 
We of the higher primates have delved into the half-known cosmic facts deeply enough to recognize also the need of cosmic fancies when facts are delayed.

-Harlow Shapley

[The scientist] must depend on the poetic myth.

—Charles I. Glicksberg

In the second half of the twentieth century one can hardly be a complete human being without at least occasionally calling to mind that community of rational beings, as yet unknown, to which we presumably belong.

-Stanislaw Lem

"What are these Martians?"

"What are we?"

-H. G. Wells

The irruption of the planetary consciousness into our tellurian world must be one of the greatest subjects that there have ever been or that can possibly be conceived of.

-Fritz Usinger

The effort to understand the universe is one of the very few things that lifts human life a little above the level of farce, and gives it some of the grace of tragedy. 
